Maurer School of Law: Indiana University

Digital Repository@Maurer Law

Indiana Law Journal

Volume 47 | Issue 1

Article 4

Fall 1971

\title{
The Supreme Court and the Antitrust Laws: 1970-1971
}

Jerrold G. Van Cise

Cahill, Gordon, Sonnett, Reindel \& Ohl

Follow this and additional works at: https://www.repository.law.indiana.edu/ilj

Part of the Antitrust and Trade Regulation Commons

\section{Recommended Citation}

Van Cise, Jerrold G. (1971) "The Supreme Court and the Antitrust Laws: 1970-1971," Indiana Law Journal: Vol. 47 : Iss. 1 , Article 4.

Available at: https://www.repository.law.indiana.edu/ilj/vol47/iss1/4

This Comment is brought to you for free and open access by the Law School Journals at Digital Repository @ Maurer Law. It has been accepted for inclusion in Indiana Law Journal by an authorized editor of Digital Repository @ Maurer Law. For more information, please contact rvaughan@indiana.edu.

\section{$\Psi$}

JEROME HALL LAW LIBRARY

INDIANA UNIVERSITY

Maurer School of Law
Bloomington 


\title{
THE SUPREME COURT AND THE ANTITRUST LAWS: 1970-197|*
}

\author{
Jerrold G. VAN Cise†
}

Once more, the Supreme Court has handed down only five significant antitrust rulings during the term of the Court which recently concluded. While many appeals raising trade regulation issues were called to the attention of the Court, few were chosen as worthy of review. In their reluctance to impose their views upon the lower courts, the Justices seem to have taken as their guide the admonition of Judge Learned Hand to the effect that every court should begin "I beseech ye in the bowels of Christ, think that ye may be mistaken"; ${ }^{1}$ and they have generally left intact the judgments below.

Once more, however, the Supreme Court in these five decisions-as in those of the preceding term-has nevertheless revealed a conviction that, when it does rule, it should condemn private restraint and commend judicial restraint. In three of its cases, it decided adversely to the defendants. In two, it withheld relief from the complainants.

\section{Substantive Rulings}

In two decisions during the 1970 Term, the Supreme Court reaffirmed its intention aggressively to apply the antitrust laws to conduct believed to be prohibited by these statutes. In one case, the Court reversed the dismissal by a federal district court of an action brought by the Government challenging the validity of a corporate merger. In another, the Court overturned the dismissal by the lower courts of a private action to recover treble damages from a labor union.

United States v. Greater Buffalo Press, Inc. ${ }^{2}$ dealt with the acquisition by Greater Buffalo Press of all the stock of International Color Printing Company. Buffalo printed color comic supplements for and scld them to newspapers, while International printed them only for King Features Syndicate, a division of the Hearst Corporation. A civil action was brought by the Government charging that the acquisition by Buffalo

* This article will be distributed by the Practising Law Institute as the 1970-1971 Supplement to the author's book, Undertaking the Antitrust Iaws (2d ed. 1970).

† Partner: Cahill, Gordon, Sonnett, Reindel \& Ohl, New York City. Member: New York and District of Columbia Bars. Chairman, Antitrust Section: American Bar Association (1960-61).

1. L. Hand, Morals in Public Life, in The SpIRIt of Liberty 229 (3d ed. 1960), quoting Oliver Cromwell's letter to the Scots before the Battle of Dunbar (1650).

2. 402 U.S. 549 (1971). 
of the stock of International violated $\S 7$ of the Clayton Act. $^{3}$ There were supplementary allegations, involving Hearst, of a violation of $\S 1$ of the Sherman Act; ${ }^{4}$ but these were settled by a consent decree. The complaint directed against Buffalo, after trial, was dismissed by the district court. ${ }^{5}$ In the course of the trial it had been shown that International had sold its stock to Buffalo, even though its profits were increasing, because it believed this alternative to be more attractive than proceeding to raise capital for necessary modernization and expansion. The Supreme Court, in a unanimous opinion, reversed. Initially, the Court found that Buffalo and International were competitors in the business of printing and selling color comic supplements :

As we read the record, the printing of color comic supplements and their sale are component parts of the color comic supplement printing business. One firm or company may both print and sell; another may print yet sell through a third organization, as does International through King. The "area of effective competition," Standard Oil Co. v. United States, 337 U.S. 293, 299-300 n. 5, comprises the business of Greater Buffalo, International, and King. There may be submarkets within this broad market for antitrust purposes (Brozen Shoe Co. v. United States, 370 U.S. 294, 325), but, as we said in United States v. Phillipsburg National Bank, 399 U.S. 350, 360 , "submarkets are not a basis for the disregard of a broader line of commerce that has economic significance."

Second, the Court found that the acquisition by Buffalo of the stock of International substantially increased concentration and restrained competition in their common area of effective competition:

Prior to the acquisition, King put pressure on International to construct a southern plant to meet Greater Buffalo's proposed expansion there. Prior to the acquisition King also induced International to cut its prices to meet competition and actually transferred a few contracts from International to Greater Buffalo because of prices.

Those practices ceased after the acquisition. Greater Buffalo acquired control of about $75 \%$ of independent color comic supplement printing, leaving King no reliable alternative supply.

3. 15 U.S.C. $\$ 18$ (1970).

4. 15 U.S.C. \& $1(1970)$.

5. 1970 Trade Cas. 88, 727 (W.D.N.Y.).

6. 402 U.S. at 552-53. 
Greater Buffalo and International who had been competitors ceased to be such. ${ }^{\text {? }}$

The Court then held that the acquisition could not be justified by the "failing company" exception to $\S 7$ of the Clayton Act:

That test is met only if two requirements are satisfied: (1) that the resources of International were "so depleted and the prospect of rehabilitation so remote that it faced the grave probability of a business failure . . . International Shoe Co. v. Federal Trade Comm'n, 280 U.S. 291, 302, and (2) that there was no other prospective purchaser for it. Citizen Publishing Co. v. United States, 394 U.S. 131, 138.

. . . King had not threatened to invoke, nor had it invoked, the six-month cancellation provision in the contract. Its expansion plans were being actively pursued and it continued to pay dividends to its owners. Indeed in the year of the sale it had shown a substantial increase in profits.

Moreover, only King and Greater Buffalo were considered as prospective purchasers; the numerous other smaller color comic supplement printers were never even approached. ${ }^{8}$

In conclusion, the Court held that the passage of time should not bar divestiture. The nature of the decree to be entered, however, was left by a majority of the Court to the district court.

Ramsey v. United Mine Workers ${ }^{9}$ involved an action brought by petitioner coal mine operators under the Sherman Act alleging that respondent union had conspired with major coal producers to impose the provisions of a collective bargaining agreement, entered into between the union and these major producers, upon all coal mine operators, with knowledge that smaller producers (unable to operate profitably under these provisions) would be driven out of business. Relief in the form of treble damages was sought. The district court dismissed the action ${ }^{10}$ on the ground that "clear proof" was lacking that such a conspiracy had been entered into; and this dismissal was affirmed by an equally divided court of appeals. ${ }^{11}$ The Supreme Court reversed. ${ }^{21}$

7. Id. at 554-55.

8. Id. at 555-56.

9. 401 U.S. 302 (1971).

10. 265 F. Supp. 388 (E.D. Tenn. 1967).

11. 416 F.2d 655 (6th Cir. 1969).

12. Mr. Justice Douglas filed a dissenting opinion, in which Justices Black, Harlan and Marshall joined. 
The Court conceded that, under $\S 6$ of the Norris-LaGuardia Act, ${ }^{13}$ the authority of officers, members and agents to commit acts on behalf of a labor union must be established by "clear proof"; but it ruled that under the Sherman Act a mere preponderance of the evidence is all that need be shown to prove an unlawful conspiracy:

In our view, $\S 6$ requires clear and convincing evidence only as to the Union's authorization, participation in, or ratification of the acts allegedly performed on its behalf. Nor do we discern any basis for our fashioning a new standard of proof applicable in antitrust actions against labor unions. Accordingly, the District Court erred in requiring petitioners' compliance with the standard of $\S 6$ in proving other elements of their treble-damage case against the Union. ${ }^{14}$

The Court then held that although a labor union may agree upon terms in a collective bargaining agreement with a multi-employer unit and seek unilaterally to impose those same terms upon other employers, it may not agree with the multi-employer unit to do so:

The Court made it unmistakably clear in Allen Bradley Co. v. Union, 325 U.S. 797, 811 (1945), that unilateral conduct by a union of the type protected by the Clayton and Norris-LaGuardia Acts does not violate the Sherman Act even though it may also restrain trade. . . . We adhere to this view. But . . . "[a] business monopoly is no less such because a union participates, and such participation is a violation of the Act." Id., at 811. Hence we also adhere to the decision in Pennington: "[T] he relevant labor and antitrust policies compel us to conclude that the alleged agreement between UMW and the large operators to secure uniform labor standards throughout the industry, if proved, was not exempt from the antitrust laws." 381 U.S., at 669 . Where a union, by agreement with one set of employers, insists on maintaining in other bargaining units specified wage standards ruinous to the business of those employers, it is liable under the antitrust laws for the damages caused by its agreed-upon conduct. ${ }^{15}$

The first of these holdings, like last year's Phillipsburg ${ }^{16}$ decision,

13. 29 U.S.C. $\S 106$ (1970).

14. 401 U.S. at 311.

15. Id. at 313 .

16. United States v. Phillipsburg Nat'1 Bank \& Trust Co., 399 U.S. 350 (1970). 
reveals that implied judicial exemptions will not lightly be read into the antitrust laws by the present Supreme Court. The second, much in the manner spelled out in the $I C C^{17}$ ruling of the past term, suggests that express legislative immunity from these laws will not readily be expanded beyond the language, strictly construed, of the statutes. The thrust of the decisions of the "Burger Court," as well as those of the "Warren Court," seems to indicate that prohibited restraints of trade which seek to escape through the eye of the antitrust needle are apt to be impaled on its point.

\section{Procedural Rulings}

The other decisions of the Supreme Court during the 1970 Term demonstrated the extent to which the present majority of the Justices seek to insure that due process is accorded to the parties both in any finding of antitrust violation and in any resulting grant of judicial relief. One of these decisions upheld, by a narrow margin, the dismissal of an action brought by the Government. The others related to relief sought by private parties.

In United States v. Armour \& Co., ${ }^{18}$ the Government had previously appealed to the Supreme Court to prevent General Host, a company engaged in the manufacture and sale of food products, from acquiring ownership of a majority of the stock of Armour \& Company, a meatpacker. A consent decree entered in 1920 had enjoined Armour from engaging directly or indirectly in the food business, and this decree was claimed by the Government to forbid any other company engaged in such business from being affiliated through stock ownership in Armour. While the appeal was pending, General Host sold its Armour stock to Greyhound Company, a regulated motor carrier which likewise was engaged in the food business. The appeal was then dismissed as moot by the Supreme Court, ${ }^{19}$ and the Government thereupon filed a petition seeking similar relief against Greyhound. The district court held, as it had when General Host's ownership of Armour stock was at issue, that the prohibition of the consent decree which enjoined Armour from acquiring a controlling interest in a food company did not proscribe another food company from acquiring such an interest in Armour. ${ }^{20}$ The Supreme Court, in a four-to-three opinion, ${ }^{21}$ affirmed the lower court's ruling.

17. United States v. ICC, 396 U.S. 491 (1970).

18. 402 U.S. 673 (1971).

19. 398 U.S. 268 (1970).

20. United States v. Swift \& Co., No. 58C613 (N.D. I11., June 30, 1970).

21. Justices Douglas, Brennan and White dissented, and Justices Black and Blackmun did not participate. 
At the outset, the Court explained that it was not upholding the legality of the acquisition. It pointed out, for example, that it was not ruling that the Government could not bar the transaction either by an action under $\S 7$ of the Clayton Act or by a proceeding to seek modification of the decree :

It [the Government] took neither of those steps, but, rather, sought to enjoin the acquisition under the decree as originally written. Thus the case presents only the narrow question whether ownership of a majority of stock in Armour by a company that engages in business forbidden to Armour by the decree, $_{3}$ in itself and without any evidentiary showing as to the consequences, violates the prohibition against Armour "directly or indirectly . . . engaging in or carrying on" that forbidden business. ${ }^{22}$

The majority opinion next noted that the Government was not contending that Greyhound was either a party to the decree or someone in active concert with such a party. Armour was in fact opposed to the "take over" of its company. Rather:

The contention is that the acquisition violates the decree since it causes Armour to be engaged in activities prohibited by the decree. The claim is that Greyhound is engaged in businesses that the decree prohibits Armour from being engaged in and the decree's purported purpose of separating the meatpackers from the retail food business is thus circumvented. ${ }^{23}$

The Court proceeded to analyze the decree and concluded that none of its provisions as presently written extended to the transaction at issue:

[T] here is no prohibition against [Armour] selling any interest to a grocery firm, or more generally against entering into an ownership relationship with such a firm. If the parties had agreed to such a prohibition, they could have chosen language that would have established the sort of prohibition that the Government now seeks. ${ }^{24}$

The Court therefore held that the consent decree was to be interpreted as written, and was not to be extended beyond its terms on the basis of an alleged intent of one of the parties:

22. 402 U.S. at 675 .

23. Id. at 677 .

24. Id. at 679 (footnote omitted). 
Thus the decree itself cannot be said to have a purpose; rather the parties have purposes, generally opposed to each other, and the resultant decree embodies as much of those opposing purposes as the respective parties have the bargaining power and skill to achieve. For these reasons, the scope of a consent decree must be discerned within its four corners, and not by reference to what might satisfy the purposes of one of the parties to it. Because the defendant has, by the decree, waived his right to litigate the issues raised, a right guaranteed to him by the Due Process Clause, the conditions upon which he has given that waiver must be respected, and the instrument must be construed as it is written, and not as it might have been written had the plaintiff established his factual claims and legal theories in litigation. $^{25}$

In Bartlett $v$. United States, ${ }^{26}$ the Government challenged a merger of Atlantic Richfield Company and Sinclair Oil Corporation under $\S 7$ of the Clayton Act. A year and a half thereafter, a proposed settlement, allegedly requiring one of the largest divestitures to date in the history of the antitrust laws, was embodied in a proposed consent judgment which was to be entered unless the Department of Justice withdrew its consent thereto prior to the expiration of a thirty-day waiting period. At 3:00 p.m. on the final day of the waiting period, a motion to intervene was filed by Richard F. Bartlett, pro se, opposing the divestiture. This application to intervene was denied by the district court as both defective in form and manifestly late. ${ }^{27}$ In addition, the lower court ruled that:

Wholly apart from these considerations, Mr. Bartlett's claim is based upon speculation as to the undesirability of the ultimate purchaser under the proposed divestiture order. The fear is unfounded because in all probability neither the Department of Justice nor this Court would approve as a purchaser a person who will not be a sufficiently strong and viable competitor to succeed Sinclair in its marketing operations in the geographic area in question. Mr. Bartlett's concern is thus premature, since the actual divestiture must first be approved by the Department of Justice or the Court under the terms of the decree, and Mr. Bartlett may at that time present his views by appropriate procedures. ${ }^{28}$

25. Id. at $681-82$ (footnote omitted).

26. 401 U.S. 986 (1971).

27. 1971 Trade Cas. 89, 881 (S.D.N.Y. 1970).

28. Id. at 89,882 . 
On appeal, this judgment of dismissal was affirmed, per curiam, by the Supreme Court. ${ }^{29}$

In Zenith Radio Corp. v. Hazeltine Research, Inc., ${ }^{30}$ HRI had sued Zenith for patent infringement, and Zenith counterclaimed for damages alleging violations of the Sherman and Clayton Acts by HRI. On a previous appeal, the Supreme Court had held that Zenith was entitled to recover damages (found by the district court to be $\$ 6,297,371$ ) arising from HRI's participation in a Canadian patent pool ${ }^{31}$ but, on remand, the court of appeals had upheld certain defenses to such a recovery based upon the statute of limitations and a prior release given to coconspirators. ${ }^{32}$ On appeal the second time, the Supreme Court reversed..$^{33}$

First, the Court held that the statute of limitations was tolled during the pendency of a prior suit brought by the Government under the antitrust laws against participants in the Canadian patent pool. This was so despite the fact that the suit had failed to name HRI either as a defendant or as a co-conspirator:

We find no indication in the legislative history of $\S 16(\mathrm{~b})$ that Congress intended it to toll the statute of limitations only against parties defendant in the Government action. . . . We see nothing destructive of Congress' purpose in holding that $\S 16(\mathrm{~b})$ tolls the statute of limitations against all participants in a conspiracy which is the object of a Government suit, whether or not they are named as defendants or conspirators therein; indeed, to so hold materially furthers congressional policy by permitting private litigants to await the outcome of Government suits and use the benefits accruing therefrom. ${ }^{34}$

Next, the Court decided that damages may be recovered by Zenith for acts occurring prior to the statutory period of limitations if, at this prior time, those damages were speculative or incapable of proof:

In antitrust and treble-damage actions, refusal to award future profits as too speculative is equivalent to holding that no cause of action has yet accrued for any but those damages already suffered. In these instances, the cause of action for future damages, if they ever occur, will accrue only on the date they

29. Mr. Justice Douglas was of the opinion that probable jurisdiction should be noted and the case set for oral argument. 401 U.S. at 986.

30. 401 U.S. 321 (1971).

31. 395 U.S. 100 (1969).

32. 418 F.2d 21 (7th Cir. 1969).

33. Justices Harlan and Stewart concurred.

34. 401 U.S. at 335-36. 
are suffered; thereafter the plaintiff may sue to recover them at any time within four years from the date they were inflicted. [citations omitted] Otherwise future damages that could not be proved within four years of the conduct from which they flowed would be forever incapable of recovery, contrary to the congressional purpose that private actions serve "as a bulwark of antitrust enforcement," [citation omitted] and that the antitrust laws fully "protect the victims of the forbidden practices as well as the public," [citation omitted]..$^{35}$

Finally, the Court rejected the defense that a prior release given to co-conspirators had released HRI, holding that the signatory parties had not intended to release it:

The straightforward rule is that a party releases only those other parties whom he intends to release.

Of course . . a plaintiff who has recovered any item of damage from one co-conspirator may not again recover the same item from another conspirator; the law, that is, does not permit a plaintiff to recover double payment. [citation omitted] However, the record below indicates that a defense of payment could not here be sustained. . . . ${ }^{86}$

The first two rulings, like last year's Armour decision, serve notice upon public and private petitioners that "short cuts" to justice are not favored by the present Supreme Court. In both instances proceedings more appropriate to the orderly administration of the law were available to the losing parties. In the third, however, as in the Union Oilit ruling of the previous term, the Court demonstrated that, once a party has properly presented and proven antitrust allegations, "legalistic" defenses to the award of relief are similarly disfavored. In short, a single standard of judicial due process is to be applied, with equal justice, to plaintiffs and to defendants.

\section{INFORMATIVE INTERVIEW}

The secret of being a bore is said to be "to tell everything." This vice has not been reflected in the relatively few decisions of the last two terms of the Supreme Court. However, a reticent, yet revealing, press

35. Id. at $339-40$.

36. Id. at 348 .

37. Simpson v. Union Oil Co., 396 U.S. 13 (1969). 
interview with the Chief Justice ${ }^{38}$ has helpfully confirmed the spirit of judicial self-restraint which has seemed to underlie these rulings. According to Chief Justice Burger:

[C] hanges in the law made by judicial decisions ought to be approached with considerable caution. It was never contemplated in our system that judges would make drastic changes by judicial decision. That is what the legislative function and the rule making function is all about.

In my conception of it, the primary role of the Court is to decide cases. ${ }^{89}$

The Chief Justice emphasized that, on the one hand, the duty of the Court should be to proceed promptly and expeditiously to dispose of the specific cases on its docket:

Inherently, the Supreme Court function is one in which nothing ought to happen very rapidly except the disposition of specific cases. In the evolution of legal doctrine, legal principle can't be sound if its growth is too fast.

Where we need speed is in the processing of the work of the courts. It is there that we find both failure and challenge. ${ }^{40}$

On the other hand, he stressed that this disposition of its case load should be consistent with insuring quality and clarity in its resultant rulings :

I would say the greatest challenge is to try to keep up with the volume of work and maintain the kind of quality that ought to come from this Court. That is the biggest single challenge I can see. A lighthouse isn't much use to seafaring travelers if the lights are dim and unclear. The Court needs time to produce clarity in its holdings. ${ }^{41}$

Therefore, in his opinion it follows that:

Young people who decide to go into the law primarily on the theory that they can change the world by litigation in the courts I think may be in for some disappointments. It is not the right way to make the decision to go into the law, and that is not the route by which basic changes in a country like ours

38. N.Y. Times, July 4, 1971, § 1, at 20, col. 1 .

39. Id.

40. Id. at col. 8 .

41. Id. at cols. 7-8. 
should be made. That is a legislative and policy process, part of the political process. ${ }^{42}$

In short, the Chief Justice would appear to agree with Daniel Webster that in the courtroom, as elsewhere, "Liberty exists in proportion to wholesome restraint." 43

\section{CONCLUSION}

The American businessman, traditionally unhappy with antitrust uncertainties, has long sought "[t]he clear and written law, the deeptrod footmarks of ancient custom . . . to keep him in the road" of antitrust compliance. Such a businessman should not lightly assume from this analysis that clarity in antitrust law is now around the corner. But he may at least take comfort that, if he should be challenged when speeding to the marketplace, the courts will not automatically accept as conclusive a charge that he has violated the antitrust traffic laws. For the promise of the past two terms of the Supreme Court is that the continuing vigor of antitrust enforcement will, at least more frequently than in the past, ${ }^{44}$ be tempered with the procedural mercy of judicial due process.

This promise of even-handed antitrust enforcement by the Supreme Court, however, apparently will not apply to unilateral trade restraints imposed by labor. Today, newspaper unions-and not a John D. Rockefeller-drive weaker competitors to the wall and create local monopolies; steel unions-and not a J. P. Morgan-force industry-wide price increases upon the nation; and transportation unions-not a Commodore Vanderbilt-bring commerce to a standstill with little justification other than "Hain't I got the power?" But the Supreme Court has reaffimed in United Mine Workers that, so long as these trade restraints are dictated to-without the cooperation of-industry, they are "congressionally permitted union activities."45

Were Adam Smith currently writing on trade restraints, he would not today be able easily to dismiss the restrictive role of labor on the rationale that "his voice is little heard and less regarded." ${ }^{\text {"46 }}$ Combinations of labor, as well as combinations of capital, are essential in our modern

42. Id. at col. 6 .

43. Speech at the Charleston Bar Dinner, May 10, 1847.

44. See, e.g., Utah Pub. Serv. Comm'n v. El Paso Natural Gas Co., 395 U.S. 464 (1969).

45. 401 U.S. at 313.

46. A. Smith, AN Inguiry into the Nature and Causes of the Wealth of Nations 149 (E. Cannan ed. 1937). 
economy. But is it not timely for spokesmen representing the consumer to petition Congress to provide that such combinations, whether of labor or of capital, are equally to be held accountable in treble damages and otherwise for inflationary restraints which pick the pocket of the public? 


\section{INDIANA LAW JOURNAL}

\begin{tabular}{lll}
\hline \hline Volume 47 & FALL 1971 & Number 1 \\
\hline
\end{tabular}

\section{INDIANA UNIVERSITY SCHOOL OF LAW \\ BOARD OF EDITORS}

Editor-in-Chief

Stephen H. Paul

Executive Editor

JoHN D. BodINE

Managing Editor

Thomas L. SHriner, Jr.
Articles and Book Review Editor Paul C. Raver

\section{Associate Editor}

Howard B. SANDLER

Note Editors
Cory Brundage
Julia C. Lamber
JoHn CarLson
RORY O'BRYAN
James R. Fisher
David S. Sidor
EDWARD A. KrRTLEY
HAROLd A. SONNEBORN

Editorial Assistants

RICHARD L. HALPERT

JAmes MCHie

EDWARD F. MCCREA

RICHARD G. BoLIN

EDWARD T. BULlard
JAY F. CoOK

Michael $J$. Huston 


\section{CONTRIBUTORS TO THIS ISSUE}

Patrick L. Baude: A.B., 1964, J.D., 1966, University of Kansas; LL.M., 1968, Harvard. Associate Professor, Indiana University School of Law, Bloomington.

Robert H. Bork: B.A., 1948, J.D., 1953, University of Chicago. Professor, Yale Law School.

Douglass G. Boshkoff: A.B., 1952, LL.B., 1955, Harvard. Professor and Associate Dean, Indiana University School of Law, Bloomington.

Gordon L. Calvert: B.A., 1943, J.D., 1945, George Washington University, Executive Director and General Counsel, Investment Bankers Association of America.

Thomas Nelson: B.A., 1952, Amherst College; LL.B., 1955, Yale Law School. Commissioner of Securities, State of Wisconsin; Chairman, Central Securities Administrators Council.

William W. Oliver: A.B., 1946, University of Kentucky ; J.D., 1949, Northwestern University. Professor, Indiana University School of Law, Bloomington.

Nigel S. Rodley: LL.B., Leeds University; LL.M., Columbia University. Research Fellow, New York University Center for International Studies; Visiting Lecturer of Political Science, Graduate Faculty, New School for Social Research.

Hugr L. Sowards: B.S., 1941, Trinity College; LL.B., 1946, Yale Law School. Professor, University of Miami School of Law.

Jerrold G. Van Cise: B.S., 1932, Princeton University; LL.B., 1935, Yale Law School. Partner, Cahill, Gordon, Sonnett, Reindel \& Oh1, New York City. 